\title{
PSYCHE.
}

\section{NOTES ON TACHINIDAE.}

BY S. WENDELL WILLISTON, LAWRENCE, KANS.

Some years ago, I described (Trans. Amer. ent. soc. xiii, p. 305) a peculiar genus of Tachinidae, under the name Melanophrys. Very recently, I have had the opportunity of examining specimens of an allied species, the types of Atropharista jurinoides Towns., now in the collection of Mr. Aldrich. A rather peculiar combination of characters which these specimens present will render the following notes of interest.

In the male of M. flavipennis Will., the eyes are conspicuously pilose. In the male of $M$. jurinoides Towns. the pilosity is inconspicuous; still hairs can be seen upon close examination. In the females of both species, the eyes are bare even under a searching examination. Hairiness of the eyes is usually considered a generic character in this family; here it is distinctly sexual. The antennae in the male of $M$. Alavipennis have the second joint not more than onefourth of the length of the third; in a female taken with the male, the second joint is about three-fourths the length of the third, - it possibly represents a distinct species. In both sexes of $M$. jurinoides, the third joint is only a little longer than the second.
In the male of the former species, there is a considerable pilosity on the thorax and abdomen, wanting in all the other specimens, both male and female. M. Aavipennis otherwise differs from M. jurinoides in the presence of a pair of median bristles on the hind margin of the second abdominal segment. In M. Aavipennis, the color-markings of the front of the male are like those of the females of both species; in $M$. jurinoides they are conspicuously different.

The singular thing about the species is that the females are so remarkably alike that one is only assured that they belong to different species by the pair of bristles on the second abdominal segment. This is all the more strange from the fact that the color-markings, as also the structure of the head, are conspicuously unlike those of allied genera. I should have mentioned the fact that I have a female of $M$. Aavipennis, agreeing more nearly with the male in its antennal structure.

Professor Townsend has recently published a useful table of the North American genera of Tachinidae (Trans. Amer. ent. soc. xix, p. 92, June, '92). Unfortunately its value 
is much impaired by a previous paper of Brauer and Bergenstamm, published in 1891 , and received the latter part of that year, in which some thirty or more additional, old or new genera are referred to North America, and which must conflict more or less with $\mathrm{Mr}$. Townsend's genera.

I cannot join with $\mathrm{Mr}$. Townsend in his sweeping condemnation of Brauer and Bergenstamm's work in this family. The descriptions of these authors are often involved and obscure, but I believe that patient study, together with ample material, will, almost always, solve the problems which they contain. Especially do I think so from the fact that these authors have given excellent figures of most of the genera (three hundred and over) known to them, and figures are usually more valuable in this family than extended descriptions. I by no means wish to affirm my faith in the validity of many of the characters used by them, but a correct interpretation of the value of these characters will be of more service than a multiplication of genera.

\section{PROCEEDINGS OF SOCIETIES.}

\section{CAMBRIDGE ENTOMOLOGICAL CLUB.}

13 January, 1893. The $175^{\text {th }}$ regular and I 7 th annual meeting (since incorporation) was held at ${ }_{5} 6$ Brattle St. Mr. S. H. Scudder was chosen chairman.

The annual reports of the Secretary, Treasurer and Librarian were presented.

The following officers for 1893 were elected : President, W. H. Ashmead of Washington; Secretary, R. Hayward; Treasurer, S. Henshaw; Librarian, S. H. Scudder; members at large of the Executive Committee, A. P. Morse and S. H. Scudder.

The annual address of the retiring President, Dr. W. J. Holland, on "Communal cocoons and the moths that weave them" was next read by $\mathrm{Mr}$. Scudder in the absence of the President. In this address Dr. Holland erected the genus Oecura and described the following new species: Oecura goodii, Anaphe clara and $A$. subsordida.

Mr. S. H. Scudder called attention to a somewhat similar habit in one of the Mexican Pieridae (Eucheira socialis) described by Westwood.

Mr. H. G. Dyar said that some individuals of Clisiocampa usually remain in the nest and undergo their transformations.

Mr. A. P. Morse, with reference to Clisiocampa, stated that he had seen a Baltimore oriole (Icterus baltimore) open a nest, but that it had considerable difficulty in opening the cocoons contained therein.

Further discussion followed in which all participated.

Mr. A. P. Morse read a short paper recording the occurrence of Paroxya atlantica at Faneuil Station, Mass., last summer and stated that he had captured there melanistic specimens.

Foreign Notes.-Mr. Charles Brongniart has succeeded $\mathrm{Mr}$. H. Lucas as assistant at the Paris museum in charge of the arthropods.

We regret to record the death of the veteran German lepidopterist, Dr. Adolph Speyer of Rhoden, the precision of whose work in the study of structure and of geographical distribution has had a good influence in science.

The eleventh part of Kolbe's Introduction to entomology continues the internal anatomy, dealing with respiration, heat, the fatty bodies and luminosity, and begins upon the digestive apparatus. 

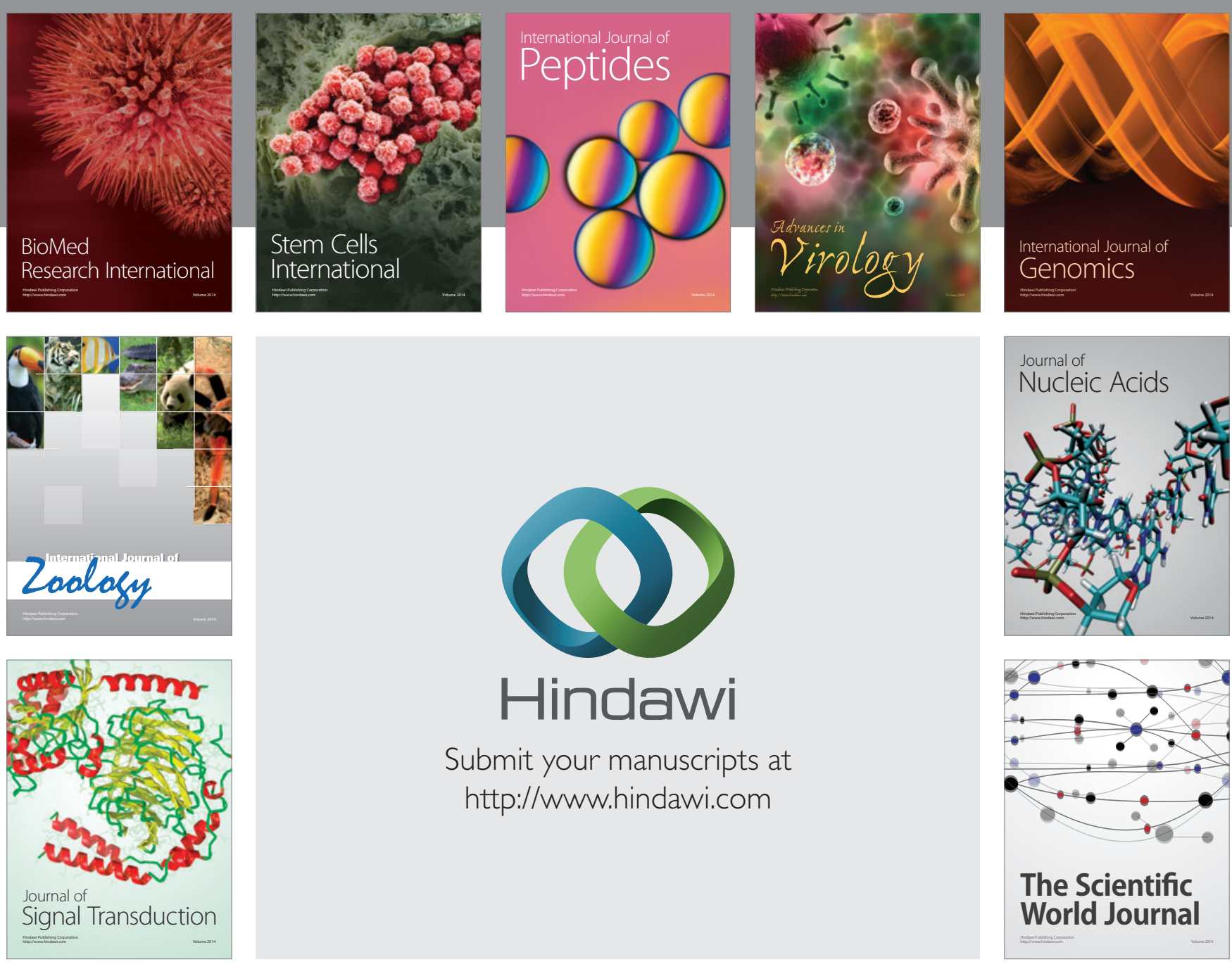

Submit your manuscripts at

http://www.hindawi.com
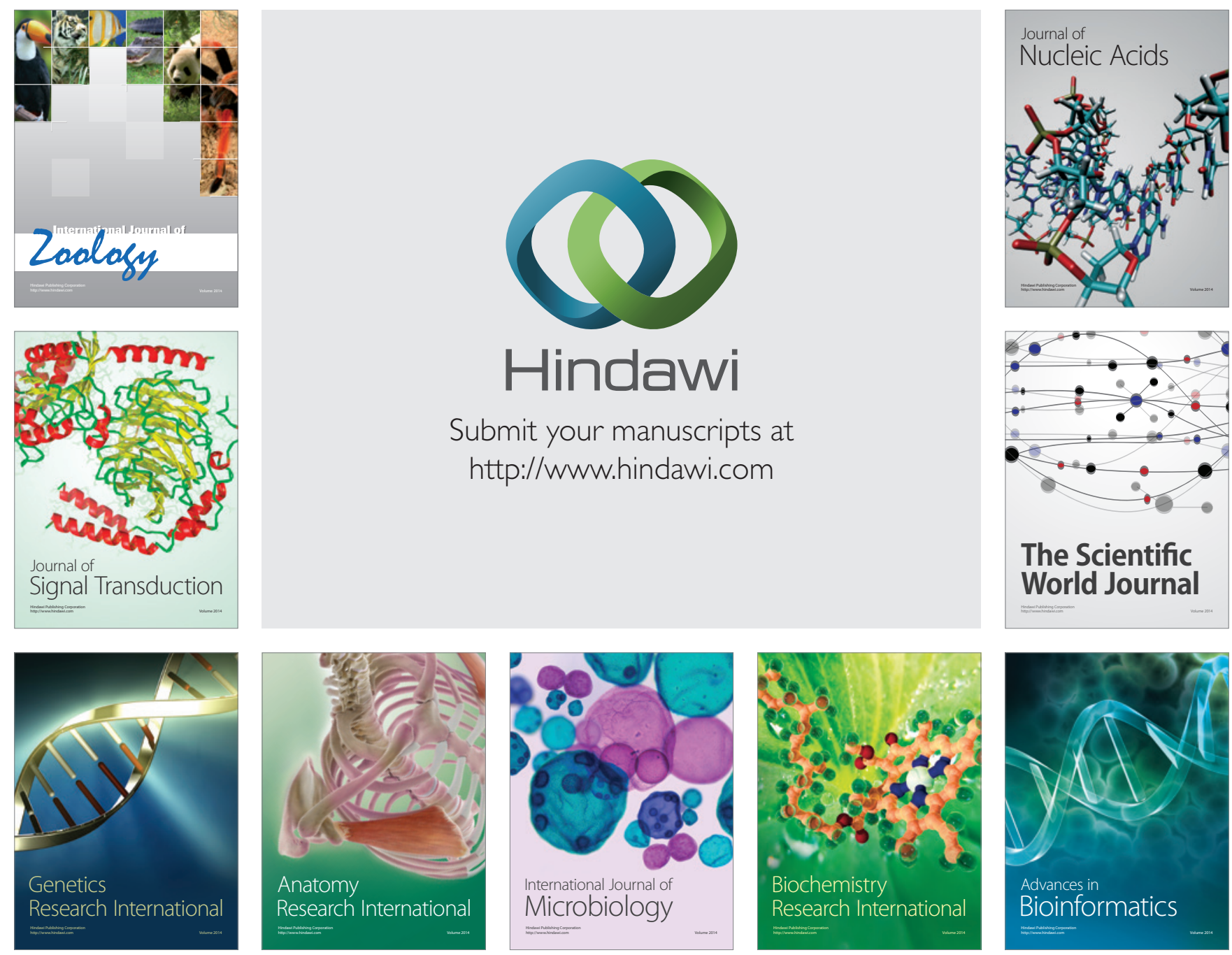

The Scientific World Journal
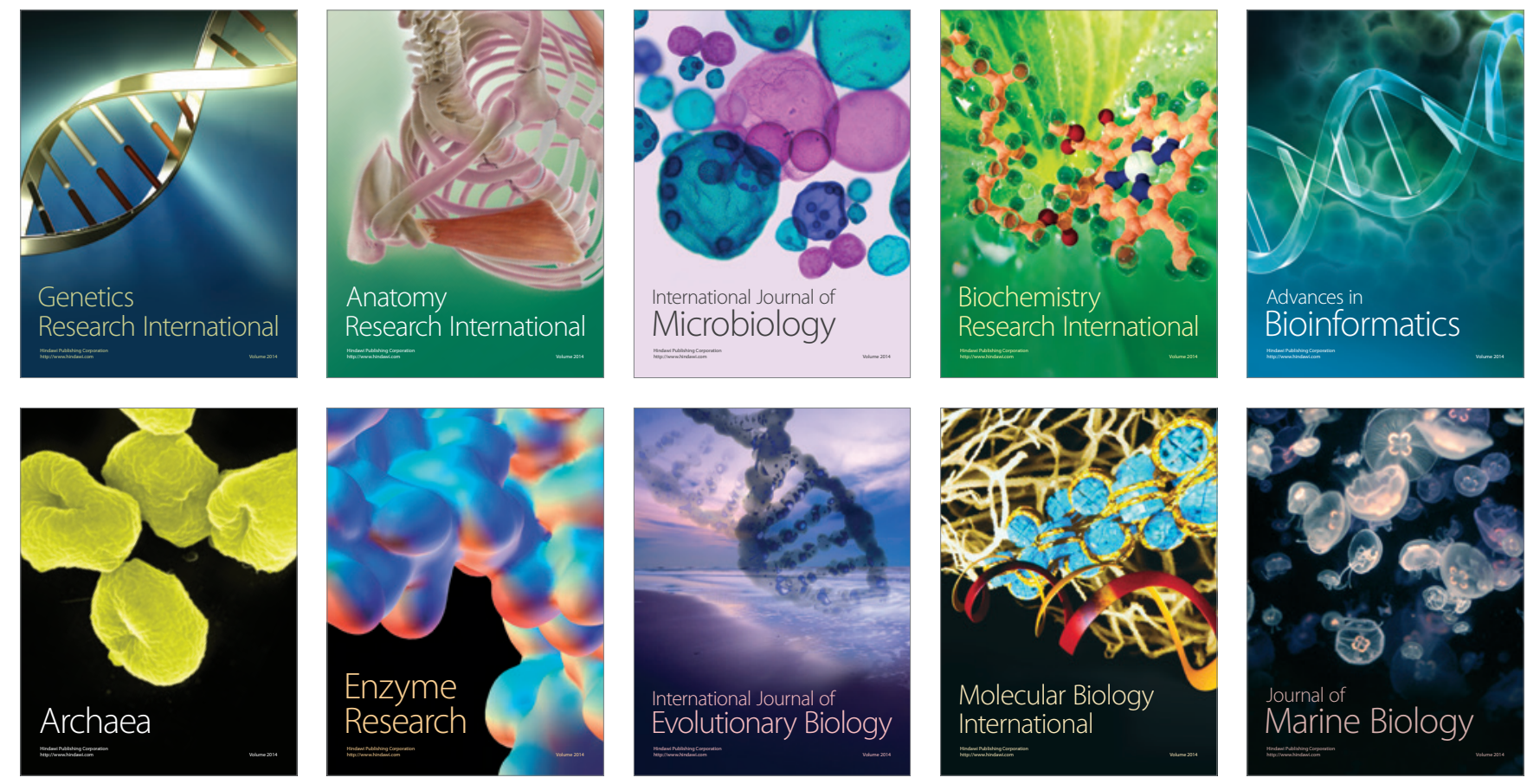